\title{
Can fracture healing be accelerated by serum transfer in head trauma cases? An experimental head trauma model in rats
}

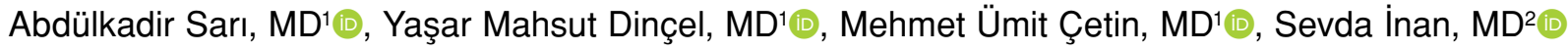 \\ ${ }^{1}$ Department of Orthopedics and Traumatology, Namık Kemal University Faculty of Medicine, Tekirdağ, Turkey \\ ${ }^{2}$ Department of Pathology, Namık Kemal University Faculty of Veterinary Medicine, Tekirdağ, Turkey
}

Fracture healing is a very complex process. ${ }^{[1]}$ Problems in fracture repair are frequently encountered and cause therapeutic problems that increase the treatment costs. ${ }^{[2]}$ High rates of union and abundant callus formation following long bone fractures accompanied by head trauma have been known for many years. ${ }^{[3]}$ Until today, the transfer of this positive effect has only been shown in in vitro studies ${ }^{[4]}$ in the literature, unfortunately, there are no in vivo studies available confirming this effect.

In the present study, we aimed to investigate whether the positive union effect caused by head trauma could be transmitted between individuals in the light of radiological and histopathological data and existing literature.

\section{MATERIALS AND METHODS}

This experimental study was conducted at Namik Kemal University, Experimental Animal Application

Received: February 02, 2021

Accepted: March 28, 2021

Published online: June 11, 2021

Correspondence: Abdülkadir Sarı, MD. Namık Kemal Üniversitesi Tıp Fakültesi Ortopedi ve Travmatoloji Anabilim Dalı, 59030

Tekirdağ, Türkiye.

E-mail: asari@nku.edu.tr

Doi: $10.52312 /$ jdrs. 2021.8

Citation: Sarı A, Dinçel YM, Çetin MÜ, İnan S. Can fracture healing be accelerated by serum transfer in head trauma cases? An experimental head trauma model in rats. Jt Dis Relat Surg 2021;32(2):306-312.

(02021 All right reserved by the Turkish Joint Diseases Foundation

This is an open access article under the terms of the Creative Commons Attribution-NonCommercial License, which permits use, distribution and reproduction in any medium, provided the original work is properly cited and is not used for commercial purposes (http://creativecommons.org/licenses/by-nc/4.0/).

\section{ABSTRACT}

Objectives: In this study, we aimed to investigate whether the positive union effect caused by head trauma could be transferred between individuals.

Materials and methods: Seventy-two male rats with an average weight of $375 \mathrm{~g}$ were used in this study and divided into four groups including 18 in each group. Group 1 consisted of serum donor rats that were exposed to head trauma, while Group 2 consisted of study rats with long bone fractures that were given the serum obtained from the rats in Group 1, Group 3 included control rats with isolated long bone fractures, and Group 4 included control rats with both head trauma and long bone fractures. For radiological evaluation, the ratio of the width of the callus to the width of the neighboring diaphysis was considered as the callus-todiaphyseal ratio in the study and control groups. Histopathological and radiological evaluations was made on Days 10, 20, and 30.

Results: In evaluation of the radiological data regarding the callusto-diaphyseal ratio, Group 3 was found to have significantly lower radiological values than Group 4 on Day $10(\mathrm{p}=0.006)$. Group 2 had significantly higher values than Group $3(\mathrm{p}=0.02)$. On Day 20 , Group 2 exhibited significantly higher radiological values than Group 3 ( $p=0.004)$, but lower than Group $4(p=0.032)$. As for Day 30 , Group 2 exhibited significantly higher radiological values than Group 3, but lower than Group 4 ( $\mathrm{p}=0.001)$. In the evaluation of the Huo scores obtained for histopathological evaluation, there was no significant difference among the groups on Days 10, 20, and 30 ( $\mathrm{p}=0.295, \mathrm{p}=0.569$, and $\mathrm{p}=0.729$, respectively).

Conclusion: Our study results suggest that the osteoinductive effect after head trauma can be transmitted between individuals by means of serum transfer.

Keywords: Fracture healing; histopathology; rat; serum transfer; traumatic brain injury.

and Research Laboratory between February 2020 and June 2020. The study protocol was approved by the Namık Kemal University Faculty of Medicine Ethics Committee for Animal Testing (Date: 2019-02-20, No: T2019-232). All animals were treated in accordance with the Guide for the Care and Use of Laboratory Animals. Seventy-two male Wistar albino rats with an average age of 3.5 months and an average weight 


\begin{tabular}{|c|c|c|c|c|}
\hline \multicolumn{5}{|c|}{$\begin{array}{l}\text { TABLE I } \\
\text { animals included in the study }\end{array}$} \\
\hline & Group 1 & Group 2 & Group 3 & Group 4 \\
\hline & $\mathrm{n}$ & $\mathrm{n}$ & $\mathrm{n}$ & $\mathrm{n}$ \\
\hline Number of rats & 18 & 18 & 18 & 18 \\
\hline Sacrification days & $1-7$ & $10-20-30$ & $10-20-30$ & $10-20-30$ \\
\hline Number of femur specimens & - & $6-6-6$ & $6-6-6$ & $6-6-6$ \\
\hline
\end{tabular}

of $375 \mathrm{~g}$ were used for the study. The rats included in the study were preoperatively monitored for $48 \mathrm{~h}$ in the laboratory and kept at $22^{\circ} \mathrm{C}$ and under $12-\mathrm{h}$ light-dark cycles. A standard pellet diet and water ad libitum were provided.

The rats were randomly divided into four groups of 18 rats each. Group 1 (donor group) consisted of serum donor rats that were exposed to head trauma, while Group 2 consisted of study rats with long bone fractures that were given the serum obtained from the rats in Group 1, Group 3 included control rats with isolated long bone fractures, and Group 4 included control rats with both head trauma and long bone fractures (Table I). Group 1 was further divided into two sub-subgroups ( $a$ and $b$ ), and the other three groups into three sub-subgroups $(a, b, c)$ according to sacrification times. The trauma models in Groups 1 and 2 were created on the same day, while head trauma and long bone fractures were also created on the same day in Group 4.

Our goal with the experimental model was to create an animal model similar to that of humans with closed head trauma. Therefore, the brain injury model which could be created by craniotomy was avoided. The experimental closed head trauma model was created with an apparatus prepared according to the Marmarou technique (Figure 1a). ${ }^{[5]}$ In order for the rats to survive after brain trauma and maintain their nutritional functions, we planned not to apply a force to the head over 0.5 joule. ${ }^{[6]}$ Thus, the upper limit was set at $50 \mathrm{~g}$ for the weight to be dropped and one meter for height.
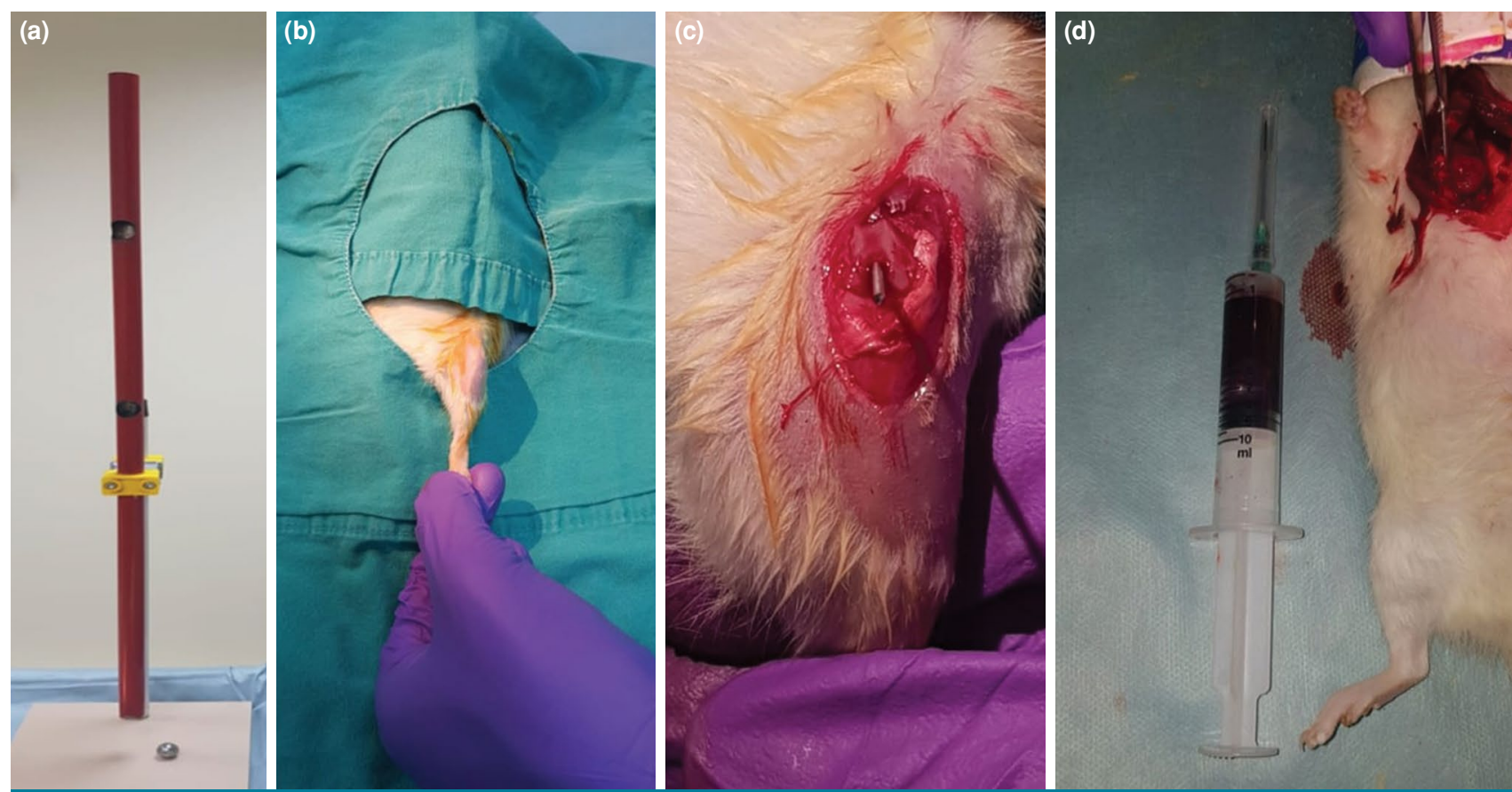

FIGURE 1. (a) Device used for the creation of the closed head trauma model. (b) Rats were shaved and disinfected with povidoneiodine. (c) Intramedullary insertion of the Kirschner wire in the femur. (d) Drawing blood from the heart after thoracotomy. 
All procedures were performed under general anesthesia. Isoflurane (FORANE; Abbott Laboratories, Abbott Park, IL, USA) was used for inhalation with a dose of $4 \%$ for induction and a dose of $2 \%$ for maintenance. Postoperative pain management was performed by subcutaneous administration of 3 to $5 \mathrm{mg} / \mathrm{kg}$ of carprofen (RIMADYL; Pfizer Inc., New York, NY, USA) with 12-h intervals within the first $24 \mathrm{~h}$. One-time subcutaneous dose of gentamicin $8 \mathrm{mg} / \mathrm{kg}$ (GENTHAVER; Osel Ilac Sanayi ve Tic. A.S., Istanbul, Turkey) was given for prophylaxis before surgery to the rats that underwent fracture fixation.

Before the femoral fracture was created, the left knee was entered using an anterior approach under sterile conditions, the patella was lateralized, and the femoral condyles were exposed. First, the femoral canal was prepared using a 1.2-mm Kirschner wire, followed by the insertion of a 1-mm Kirschner wire into the femur. The proximal of the wire was slightly bent to prevent the wire from retracting back into the joint. ${ }^{[7]}$ After cutting the wire at the joint level, the wound was closed with $3 / 0$ absorbable sutures and $3 / 0$ silk sutures (Figure $1 b$ and c). For the fracture model, the experimental one-sided closed fracture model was created on the left legs of the rats according to the principles defined by Bonnarens and Einhorn $^{[8]}$ and used in several experimental fracture healing studies. ${ }^{[9,10]} \mathrm{A} 150 \mathrm{~g}$ weight was dropped from one meter height to the thigh.

Four rats that were observed to have developed segmental fractures during the radiological controls were excluded from the study and were substituted with new rats. After the procedure, the rats were placed in cages in groups of four and were allowed to move freely.

The rats in Group 1a were sacrificed $24 \mathrm{~h}$ after the procedure, while rats in Group $1 \mathrm{~b}$ were sacrificed on Day 7 by taking blood from their hearts after open thoracotomy (Figure 1d). To prevent the change in serum content due to hemolysis in the blood samples obtained, the blood was discharged with a $45^{\circ}$ inclination after the needle of the injector was removed. The samples were centrifuged at 3,000 rpm for $10 \mathrm{~min}$ and the serum part was separated. Serums $(2 \mathrm{~mL})$ obtained from Group 1a were given to Groups $2 \mathrm{a}, 2 \mathrm{~b}$ and $2 \mathrm{c}$ without delay, and the serums $(2 \mathrm{~mL})$ obtained from Group $1 b$ were given intraperitoneally to Groups $2 \mathrm{a}, 2 \mathrm{~b}$ and $2 \mathrm{c}$. The effect was standardized by giving equal amounts of serum $(2 \mathrm{~mL})$ to each rat in Group 2 each time. Following the serum administration, Group 2 rats did not demonstrate any allergic or reject reactions. The rats in Groups 2a, 3a and 4a were sacrificed on Day 10, the rats in Groups $2 \mathrm{~b}, 3 \mathrm{~b}$ and $4 \mathrm{~b}$ on Day 20, and the rats in Groups 2c, 3c and $4 \mathrm{c}$ on Day 30 via cervical dislocation performed under high-dose anesthesia.

After sacrification, femoral bones were disarticulated from the hip joint and direct radiographs were taken (Figure 2a-c). In all groups, the radiographs taken on Days 10,20 , and 30 were evaluated according to the callus-to-diaphyseal ratio defined by Spencer. ${ }^{[11]}$ In this measurement, we took the ratio of the width of the callus at its widest point to the width of the diaphysis adjacent to the healing fracture site; with both measurements being taken
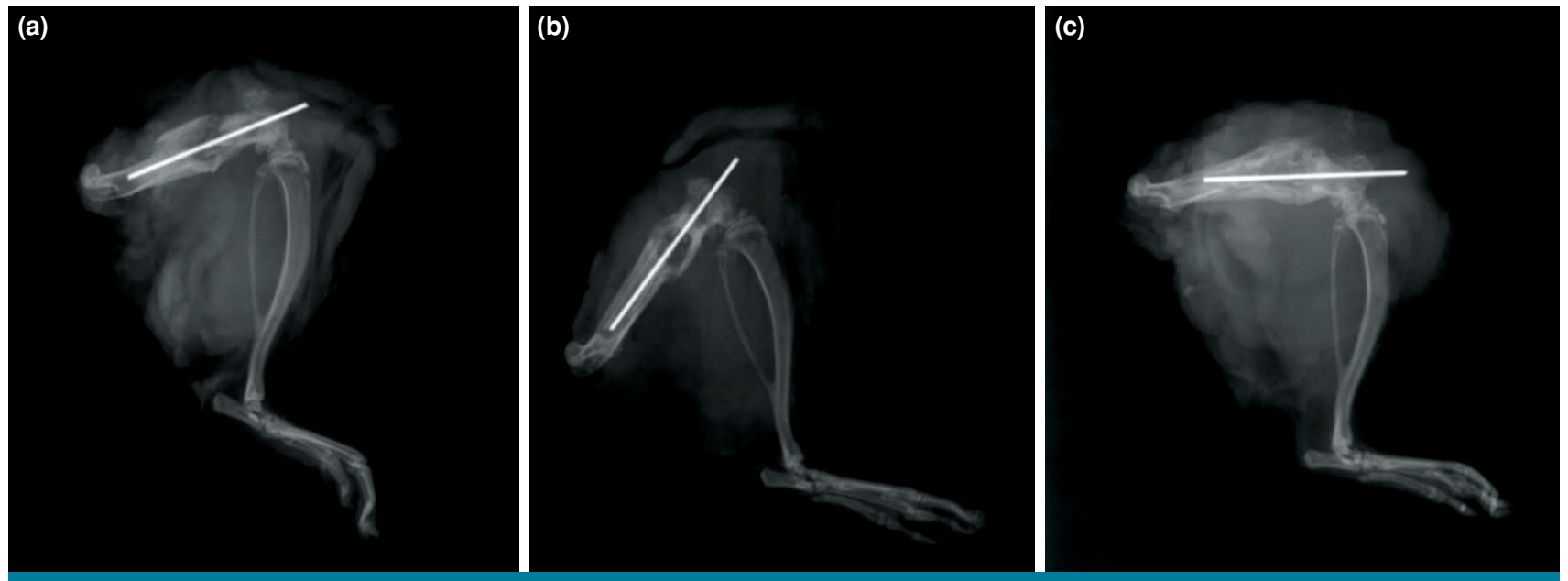

FIGURE 2. (a) Postoperative $30^{\text {th }}$ day X-ray image from the study group given serum (Group $2 \mathrm{c}$ ). (b) Postoperative $30^{\text {th }}$ day $\mathrm{X}$-ray image from the control group with isolated femur fractures (Group 3c). (c) Postoperative $30^{\text {th }}$ day X-ray image from the control group with concomitant head trauma and femur fractures (Group 4c). 
by drawing right angles to the long axis of the bone. The measurements were carried out by an orthopedic surgeon who was blinded to the group allocation.

Histopathological examinations were performed by a veterinary pathologist who was blinded to the study design and setting. After the rats were euthanized, the bone tissue from each group were fixed in $10 \%$ phosphate buffered formalin solution at room temperature and then decalcified in $10 \%$ formic acid solution. The specimens were neutralized with ammonia solution for $30 \mathrm{~min}$, washed for one day, dehydrated in graded ethanol and embedded in paraffin. Five-micrometer thick sections were mounted and stained with hematoxylin and eosin (H-E). Each slide was evaluated semi-quantitatively under the light microscope (Olympus CX41; Olympus Corporation, Tokyo, Japan) by selecting four different sections and classified according to the histological grading system of Huo et al. ${ }^{[12]}$ (Figure 3, Table II).

\section{Statistical analysis}

Statistical analysis was performed using the NCSS version 2007 software (NCSS LLC, Kaysville, UT, USA). Descriptive data were expressed in mean \pm standard deviation (SD), median (min-max), or number and frequency. The distribution of the data was evaluated using the Shapiro-Wilk test. The Kruskal-Wallis test was used to compare the quantitative data from three or more groups that did not meet a normal distribution. The Friedman test was utilized for comparisons of three time periods and above, and the Wilcoxon test was used to determine the differences. A $p$ value of $<0.05$ was considered statistically significant.

\section{RESULTS}

Callus-to-diaphyseal ratios according to Spencer ${ }^{[11]}$ were obtained from the lateral radiographs taken after sacrification on Days 10, 20, and 30. In all three groups, radiological scores showed a gradual
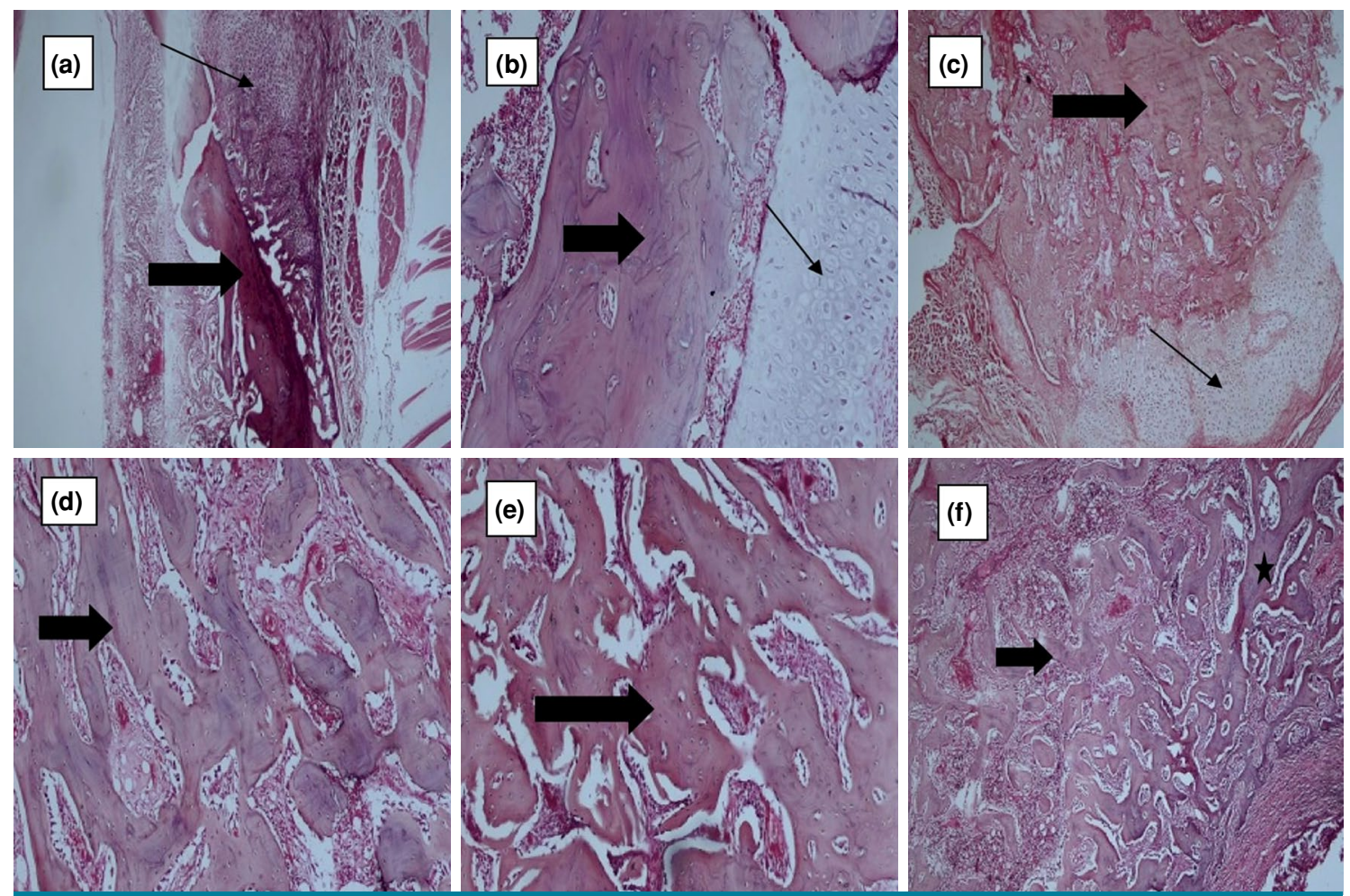

FIGURE 3. Histopathological appearance of the fracture. The thin arrows indicate cartilage tissues, the thick arrows show immature (woven) bone tissues, and the star shape point to mature bone tissues. (a) Marked mainly cartilage tissue and small amount of immature tissue (Group 3a) ( $\mathrm{H}-\mathrm{E}, \times 40$ magnification). (b) Marked equal amount of cartilage tissue and immature bone tissue (Group 3b) (H-E, $\times 100$ magnification). (c) Marked mainly immature bone tissue and small amount cartilage tissue (Group 4b) (H-E, $\times 40$ magnification). (d) Marked immature bone tissue (respectively, Group 2c) (H-E, x100 magnification). (e) Marked immature bone tissue (respectively, Group 3c) (H-E, $\times 100$ magnification). (f) Marked immature bone tissue and small amount of mature bone tissue (Group 4c) (H-E, $\times 40$ magnification). 


\begin{tabular}{|cl|}
\multicolumn{1}{c|}{ TABLE II } \\
Histological scoring system of Huo et al. ${ }^{[12]}$ \\
\hline 1 & Fibrous tissue \\
2 & A large amount of fibrous tissue and a small amount of cartilage tissue \\
3 & Equal ratio of fibrous tissue and cartilage tissue \\
4 & A large amount of cartilage tissue and a small amount of fibrous tissue \\
5 & Cartilaginous tissue \\
6 & A large amount of cartilage tissue and a small amount of immature bone tissue \\
7 & Equal ratio of cartilage tissue and immature bone tissue \\
8 & A large amount of immature bone tissue and a small amount of cartilage tissue \\
9 & Fracture healing with immature bone \\
10 & Fracture healing with mature bone
\end{tabular}

increase from Day 10 to 30 ( $\mathrm{p}=0.002$ for Groups 2, 3 and 4 each).

Statistically significant radiological differences were detected among the groups at each time period $(\mathrm{p}<0.05)$. On Day 10, Group 3a showed statistically significant lower radiological values than Group 4a ( $\mathrm{p}=0.006)$, and Group 2a had statistically significant higher values than Group 3a $(\mathrm{p}=0.02)$. On Day 20, Group $2 b$ exhibited significantly higher radiological values than Group 3b ( $\mathrm{p}=0.004)$, but lower than Group $4 \mathrm{~b}(\mathrm{p}=0.032)$. Group $4 \mathrm{~b}$ also had significantly higher values than Group $3 b(p=0.004)$. As for Day 30, group $2 c$ exhibited higher radiological values than Group 3c, but lower than Group 4c $(\mathrm{p}=0.001)$ (Table III).

The radiological score in Group 2a on Day 10 was significantly lower than the Group $2 b$ values on Day 20 ( $p=0.001)$. Similarly, the radiological score in Group 2a on Day 10 and the score in Group 2b on Day 20 was significantly lower than the score in Group 2c on Day 30 ( $p=0.001)$. The radiological score in Group 3c on Day 30 was significantly higher than the values in Groups $3 a$ and $3 b(p=0.001)$. The radiological score in Group $3 \mathrm{~b}$ was higher than that of Group 3a $(\mathrm{p}=0.001)$. Also, the radiological score in Group 4c on Day 30 was significantly higher than the values in Groups $4 a$ and $4 b(p=0.001)$. The radiological score in Group $4 \mathrm{~b}$ was higher than the score in Group 4a $(\mathrm{p}=0.001)$.

In evaluation of the Huo scores obtained for histopathological evaluation, there was no statistically significant difference among the groups on Days 10, 20 , and $30(p=0.295, p=0.569$, and $p=0.729$, respectively) (Table IV).

\begin{tabular}{|c|c|c|c|c|c|}
\hline \multicolumn{6}{|c|}{$\begin{array}{c}\text { TABLE III } \\
\text { adiological meas }\end{array}$} \\
\hline & $\mathrm{n}$ & Mean $\pm S D$ & Median & Min-Max & $p$ \\
\hline \multicolumn{6}{|l|}{ Day 10} \\
\hline Group 2a & 6 & $1.4 \pm 0.2$ & 1.45 & $1.2-1.6$ & \\
\hline Group 3a & 6 & $1.2 \pm 0.1$ & 1.2 & $1.1-1.3$ & $0.012^{*}$ \\
\hline Group 4a & 6 & $1.5 \pm 0.1$ & 1.5 & $1.3-1.6$ & \\
\hline \multicolumn{6}{|l|}{ Day 20} \\
\hline Group 2b & 6 & $2.2 \pm 0.2$ & 2.25 & $2-2.4$ & \\
\hline Group 3b & 6 & $1.9 \pm 0.1$ & 1.9 & $1.8-2$ & $0.001 \dagger$ \\
\hline Group 4b & 6 & $2.4 \pm 0.1$ & 2.4 & $2.3-2.5$ & \\
\hline \multicolumn{6}{|l|}{ Day 30} \\
\hline Group 2c & 6 & $2.7 \pm 0.1$ & 2.7 & $2.6-2.8$ & \\
\hline Group 3c & 6 & $2.5 \pm 0.1$ & 2.5 & $2.4-2.6$ & $0.005+$ \\
\hline Group 4c & 6 & $2.8 \pm 0.2$ & 2.75 & $2.6-3$ & \\
\hline
\end{tabular}




\begin{tabular}{|lccccc|}
\multicolumn{5}{c}{ TABLE IV } \\
\multicolumn{5}{c}{ Comparison of the histopathological scores by groups } \\
\hline & $\mathrm{n}$ & Mean \pm SD & Median & Min-Max & $p^{*}$ \\
\hline Day 10 & & & & & \\
Group 2a & 6 & $6.3 \pm 0.5$ & 6 & $6-7$ & \\
Group 3a & 6 & $6 \pm 0.6$ & 6 & $5-7$ & 0.295 \\
Group 4a & 6 & $6.7 \pm 0.8$ & 6.5 & $6-8$ & \\
Day 20 & & & & & \\
Group 2b & 6 & $7.5 \pm 0.6$ & 7.5 & $7-8$ & \\
Group 3b & 6 & $7.3 \pm 0.8$ & 7.5 & $6-8$ & 0.569 \\
Group 4b & 6 & $7.8 \pm 0.8$ & 8 & $7-9$ & \\
Day 30 & & & & & \\
Group 2c & 6 & $9 \pm 0.6$ & 9 & $8-10$ & \\
Group 3c & 6 & $9 \pm 0$ & 9 & $9-9$ & 0.729 \\
Group 4c & 6 & $9.2 \pm 0.4$ & 9 & $9-10$ & \\
\hline SD: Standard deviation; ${ }^{*}$ Kruskal-Wallis test. & & & \\
\hline
\end{tabular}

\section{DISCUSSION}

Our study shows that taking serum samples from patients with head trauma and transferring them to patients with long bone fractures accelerates the union process and supports the formation of radiologically significant callus in the early period.

There is a consensus in the literature that fracture healing in the long bones is positively affected after traumatic brain injury. ${ }^{[13]}$ Giannoudis et al. ${ }^{[14]}$ reported that femoral fractures after head trauma could heal faster with a greater callus-to-diaphyseal ratio. Arik et al. ${ }^{[15]}$ found a significantly larger callus mass, compared to the control group, in the experimental rat models on the first and third weeks after head trauma. The authors concluded that head trauma increased the fracture healing speed in the early period.

The mechanisms affecting fracture union after head trauma are still not fully understood. In a recent study, ${ }^{[16]}$ it was claimed that the combination of relative inhibition of the sympathetic nervous system and non-hormonal mechanisms was effective. In the same study, parathyroid hormone levels peaked in the first $24 \mathrm{~h}$ in human serum samples from cases with head trauma and from cases who had head trauma accompanied by long bone fractures, and that both groups had higher values than the control group with isolated long bone fractures. In another study, parathyroid hormone levels in the samples taken from human cases peaked in the first 6 to $24 \mathrm{~h}$ after head trauma, and the osteoinductive effect reached its maximum level in $24 \mathrm{~h}$ after traumatic brain injury and decreased slowly after the first week. ${ }^{[4]}$ In our study, serum samples were obtained from the donor group at $24 \mathrm{~h}$ and at the first week, and were transferred to cases with femur fractures in accordance with the literature data.

Although the phases of fracture healing differ very little in experimental rat studies, it may be classified as follows: hematoma (Days 1 to 5), callus formation (Days 5 to 10), mineralization (Days 10 to 20), and hardening of the callus (Days 20 to 28), followed by the bone remodeling phase. ${ }^{[17]}$ In another study, hematoma and inflammation phase were observed on Day 7, the callus phase on Day 14, and the ossification phase on Day 21. ${ }^{[18]}$ The $10^{\text {th }}$ day in our study delineates the early callus phase of fracture healing, the $20^{\text {th }}$ day delineates the mineralization phase, and the $30^{\text {th }}$ day the ossification phase before bone remodeling.

In the current literature, there are studies investigating the effects of osteoinductive serums on cell cultures in an in vitro setting. Bidner et al. ${ }^{[19]}$ showed that serums obtained from head trauma cases caused an increased proliferation effect on rat osteoblast cell cultures, compared to serums obtained from healthy controls and cases with isolated fractures. Gautschi et al. ${ }^{[4]}$ showed that serum samples obtained from cases with long bone fractures accompanied by head trauma had a greater proliferative effect on human fetal osteoblastic cells and human osteoblasts, compared to serums obtained from cases with isolated head traumas and cases with isolated long bone fractures. Boes et al. ${ }^{[20]}$ also demonstrated that, when incubated with serum from brain-damaged rats, human stromal stem cells 
had reproduced in higher numbers than what was anticipated and suggested that brain-derived factors mediated a mitogenic effect on osteoprogenitor cells through the bloodstream.

In our study, the in vivo efficacy of the osteoinductive effect due to head trauma was investigated for the first time. When callus-todiaphyseal ratios were examined, we found that callus formation increased from Day 10 to Day 30 in all groups. We also observed that the serumtransferred group had better radiological scores than the isolated fracture group in all periods after fracture. Although there was no statistically significant difference among the histopathological scores of the groups, microscopic examinations confirmed a predominant presence of cartilage or equal presence of cartilage and immature bone tissue in all groups on Days 10 and 20. On Day 30, a denser immature bone tissue and less cartilage tissue were observed. In all measurements, Group 4 had more dense immature tissue and less collagen tissue than Groups 2 and 3 and demonstrated a better healing process. Radiologically, our results demonstrate that serum transfer had a positive effect on the early callus formation and mineralization periods of fracture healing, although they are not histopathologically confirmed. We also noticed that this effect continued in the early remodeling phase.

Our study has some limitations. First, the rats with head trauma and long bone fractures could be added to the study as a serum donor group instead of those only with head trauma. Second, the union of long bone fractures could be evaluated biomechanically. In our study, possible infection and nonunion conditions were reduced by avoiding the creation of an open fracture model, and cases with partial fractures that occurred after the closed fracture model were excluded. Finally, micro-computed tomography could have been used for radiological evaluation, as it would be more objective, and Spencer scoring was used instead of Lane and Sandhu scoring.

In conclusion, our study showed that the osteoinductive effect after head trauma can be transmitted between individuals by means of serum transfer. We believe that the present study results would provide an additional contribution to the development of new therapeutic modalities following future studies on humans.

\section{Declaration of conflicting interests}

The authors declared no conflicts of interest with respect to the authorship and/or publication of this article.

\section{Funding}

The authors received no financial support for the research and/or authorship of this article.

\section{REFERENCES}

1. Sathyendra V, Darowish M. Basic science of bone healing. Hand Clin 2013;29:473-81

2. Szczęsny G. Fracture healing and its disturbances. A literature review. Ortop Traumatol Rehabil 2015;17:437-54.

3. Newman RJ, Stone MH, Mukherjee SK. Accelerated fracture union in association with severe head injury. Injury 1987;18:241-6.

4. Gautschi OP, Cadosch D, Frey SP, Skirving AP, Filgueira L, Zellweger R. Serum-mediated osteogenic effect in traumatic braininjured patients. ANZ J Surg 2009;79:449-55.

5. Marmarou A, Foda MA, van den Brink W, Campbell J, Kita H, Demetriadou K. A new model of diffuse brain injury in rats. Part I: Pathophysiology and biomechanics. J Neurosurg 1994;80:291-300.

6. Silva Ddos S, Brito JN, Ibiapina JO, Lima MF, Medeiros AR, Queiroz $\mathrm{BH}$, et al. Traumatic brain injury: Clinical and pathological parameters in an experimental weightdrop model. Acta Cir Bras 2011;26:94-100.

7. Dincel YM, Alagoz E, Arikan Y, Caglar AK, Dogru SC, Ortes F, et al. Biomechanical, histological, and radiological effects of different phosphodiesterase inhibitors on femoral fracture healing in rats. J Orthop Surg (Hong Kong) 2018;26:2309499018777885.

8. Bonnarens F, Einhorn TA. Production of a standard closed fracture in laboratory animal bone. J Orthop Res 1984;2:97-101.

9. Koçkara N, Sofu H, Issin A, Çetinkaya M, Tayfur M, Süleyman B. Pregabalin does not affect fracture healing adversely. Eklem Hastalik Cerrahisi 2017;28:19-24.

10. Halıcı M, Öner M, Güney A, Canöz Ö, Narin F, Halıcı C. Melatonin promotes fracture healing in the rat model. Eklem Hastalik Cerrahisi 2010;21:172-7.

11. Spencer RF. The effect of head injury on fracture healing. A quantitative assessment. J Bone Joint Surg [Br] 1987;69:525-8.

12. Huo MH, Troiano NW, Pelker RR, Gundberg CM, Friedlaender GE. The influence of ibuprofen on fracture repair: Biomechanical, biochemical, histologic, and histomorphometric parameters in rats. J Orthop Res 1991;9:383-90.

13. Rockwood CA, Green DP. Bone and joint healing. In: Koval KJ, Bucholz RW, Heckman JD, Court-Brown C, Tornetta P, editors. Rockwood and Green's Fractures in Adults. Chapter 8. 6th ed. Philadelphia: Lippincott; 2006. p. 297-312.

14. Giannoudis PV, Mushtaq S, Harwood P, Kambhampati S, Dimoutsos M, Stavrou Z, et al. Accelerated bone healing and excessive callus formation in patients with femoral fracture and head injury. Injury 2006;37 Suppl 3:S18-24.

15. Arık M, Ekinci Y, Gürbüz K, Batın S. The effects of focal brain damage on fracture healing: An experimental rat study. Eklem Hastalik Cerrahisi 2019;30:267-74.

16. Khallaf FG, Kehinde EO, Hussein S. Bone healing and hormonal bioassay in patients with long-bone fractures and concomitant head injury. Med Princ Pract 2016;25:336-42.

17. Schmidmaier G, Wildemann B, Heeger J, Gäbelein T, Flyvbjerg A, Bail HJ, et al. Improvement of fracture healing by systemic administration of growth hormone and local application of insulin-like growth factor-1 and transforming growth factorbeta1. Bone 2002;31:165-72.

18. Alıç T, Çıraklı A, Şahin Y, Tomak Y. Effects of cilostazol on fracture healing: An experimental study. Acta Orthop Traumatol Turc 2016;50:103-10.

19. Bidner SM, Rubins IM, Desjardins JV, Zukor DJ, Goltzman D. Evidence for a humoral mechanism for enhanced osteogenesis after head injury. J Bone Joint Surg [Am] 1990;72:1144-9.

20. Boes M, Kain M, Kakar S, Nicholls F, Cullinane D, Gerstenfeld L, et al. Osteogenic effects of traumatic brain injury on experimental fracture-healing. J Bone Joint Surg [Am] 2006;88:738-43. 